2014-05

\title{
Strategizing Britain's role in the world
}

\section{GASKARTH, J}

http://hdl.handle.net/10026.1/15760

10.1111/1468-2346.12127

International Affairs

Oxford University Press (OUP)

All content in PEARL is protected by copyright law. Author manuscripts are made available in accordance with publisher policies. Please cite only the published version using the details provided on the item record or document. In the absence of an open licence (e.g. Creative Commons), permissions for further reuse of content should be sought from the publisher or author. 


\section{Strategizing Britain's role in the world}

\section{JAMIE GASKARTH}

British foreign policy is in danger of strategic drift. A series of international crises in recent years, from the Arab Spring to the Syrian civil war and the Ukrainian revolution, have been met with confused responses lacking a sense of overarching national goals or a systematic consideration of how to achieve them. Upon entering office in 20Io, Foreign Secretary William Hague set out the idea that the UK was now operating within a networked world and argued that it should exploit the possibilities of this environment to further British interests. ${ }^{\mathrm{I}} \mathrm{He}$ criticized New Labour for falling into 'a chasm of their own making between rhetoric and action in large areas of foreign policy' and suggested that the coalition government would bring a more strategic sensibility to its policy-making. ${ }^{2}$ However, four years on, problems remain. Schisms are developing between the public and elites on important issues such as when it is appropriate to use military force abroad and whether the UK should remain a member of the European Union.

The difficulty, as many analysts of foreign policy have pointed out, is that consideration of strategy is heavily reliant upon the identity ascribed to the UK as a global actor. ${ }^{3}$ Hague defined strategy as 'some sense of what we are trying to achieve as a country over a longer period'. ${ }^{4}$ Yet, as the Public Administration Select Committee (PASC) has argued: 'Strategic aims cannot be set or adjudicated without an articulated account of who "we" are and what we believe, both about ourselves and the world.'5 Hague's discussion of British identity in his strategic speeches amounted to a few brief sentences on UK democracy and the rule of law. ${ }^{6}$

I William Hague, 'Britain's foreign policy in a networked world', speech given on I July 20Io, https://www. gov.uk/government/speeches/britain-s-foreign-policy-in-a-networked-world--2, accessed I3 April 2014.

2 William Hague, 'Britain's values in a networked world', speech given at Lincoln's Inn, London, Is Sept. 20Iо, https://www.gov.uk/government/speeches/foreign-secretary-britains-values-in-a-networked-world, accessed Io April 20I4.

3 Patrick Porter, 'Why Britain doesn't do grand strategy', RUSI Journal I55: 4, 20I0, p. I0; House of Lords/House of Commons, Joint Committee on the National Security Strategy, First review of the National Security Strategy 2010, 27 Feb. 20I2, HC I384, http://www.publications.parliament.uk/pa/jt20IoI2/jtselect/jtnatsec/265/265. pdf, pp. I8-I9, accessed Io April 20I4; PASC, Who does UK national strategy? Further report, 25 Jan. 20II, http:// www.publications.parliament.uk/pa/cm20IoII/cmselect/cmpubadm/713/71303.htm, para. 7, accessed ro April 20I4. See also Christopher Hill, 'Tough choices', World Today, April 20Io, pp. II-I4. Strategy is understood here to mean thinking about how, given their means, actors can achieve their policy goals; see Steven Jermy, Strategy for action (London: Knightstone, 20II), p. I8.

4 PASC, Who does UK national strategy?, Ev. I6.

5 PASC, Who does UK national strategy?, para. 7.

6 Hague, 'Britain's values'. 
The coalition's Strategic Defence and Security Review (SDSR) was promoted as 'a fundamental reappraisal of Britain's place in the world'; ${ }^{7}$ however, the subsequent report was criticized for lacking any substantial analysis of the UK's place in the world and how this linked with the domestic political community. ${ }^{8}$ This shortcoming is very much in keeping with UK foreign policy-makers' traditional reluctance to reflect on questions of national identity. ${ }^{9}$ The PASC has suggested that this needs to change, and that unstated assumptions 'need to be exposed so that they may be tested and, if necessary, altered'. ${ }^{\text {IO }}$

Two key factors driving the need for some reflection on British identity and how the nation wishes to act abroad are the impact of austerity and the rise of new poles of power in the international structure. With regard to austerity, a report for the Institute for Public Policy Research in 2009 asserted: 'Most serious commentators now believe the situation cannot continue as it is ... fundamental choices are necessary. The attempt to maintain the full spectrum of conventional combat capabilities at current scale has produced acute strains on resources and, increasingly, on operational effectiveness. 'II Similarly, a joint parliamentary committee report on the National Security Strategy argued in 2oro that: 'Given the UK's low economic growth rate ... we believe it is wholly unrealistic not to expect any diminution in the UK's power and influence in the medium and long term. ${ }^{\text {I2 }}$ Commentators predicted that the UK, facing a reduced capacity to act, would have to change its behaviour and draw back from international commitments. ${ }^{\mathrm{I}} \mathrm{In}$ doing so, the country would have to become a very different kind of actor, with a different self-identity.

At the same time, the economic rise of Brazil, China, India and a newly assertive Russia is predicted to bring a 'historic shift of relative wealth and economic power from West to East' in coming decades. ${ }^{\text {I4 }}$ Longstanding assumptions about Britain's status and leadership in global forums, about alliance patterns and about policy behaviour are under scrutiny. In response, parliamentarians assert that national strategy 'should be based on a realistic vision of the UK's future place in the world, which will both shape, and be shaped by, the UK's interests and objectives. ${ }^{\text {Is }}$ A genuinely strategic approach to foreign policy-making therefore requires policy-makers to ask: what kind of an actor does the United Kingdom want to be in international politics?

7 Ministry of Defence (MoD), Strategic Defence and Security Review (London, 20Io).

8 Defence Committee, 'Towards the next Defence and Security Review', Seventh Report, I8 Dec. 20I3, http:// www.publications.parliament.uk/pa/cm20I3I4/cmselect/cmdfence/I97/19705.htm; Church of England Archbishops Council, 'Submission to the Defence Select Committee Inquiry', Feb. 20II, http://www.church ofengland.org/media/I3I2982/post\%20sdsr\%2osubmission\%2ocofe.doc, both accessed Io April 2014.

9 John Coles, Making foreign policy: a certain idea of Britain (London: John Murray, 2000), p. II ; Peter Mangold, Success and failure in British foreign policy (Basingstoke: Palgrave, 200I), pp. 5, 68. A rare example of open reflection was provided by the I995 FCO conference on 'Britain in the world'.

Io PASC, Who does UK national strategy?, para. 7.

II IPPR, Shared responsibilities: a national security strategy for the UK (London, 30 June 2009), p. 47.

I2 House of Lords/House of Commons, Joint Committee on the NSS, First review, para. 29.

I3 Stryker McGuire and Christopher Werth, 'Forget the Great in Britain', Newsweek International I7 Aug. 2009.

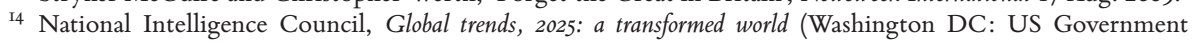
Printing Office, 2008), p. I.

is House of Lords/House of Commons, Joint Committee on the NSS, First review, pp. I8-I9. 
This question has periodically surfaced in British foreign policy debates under the guise of consideration of Britain's role in the world. ${ }^{16}$ However, the term 'role' is often used loosely and rarely leads to a full appraisal of the range of identity and policy positions available to Britain's policy-makers. ${ }^{\mathrm{I}}$ This article aims to address this gap in the literature by offering a framework for understanding how states orient themselves in global politics by playing roles. The roles states adopt in international relations are shaped by domestic self-identities and political pressures as well as the expectations of other states and actors globally. ${ }^{\mathrm{I}}{ }^{2}$ The pattern of roles that any one state adopts can be seen as amounting to a role orientation. By analysing a range of orientations the UK could adopt towards the international environment, the article aims to open up space for policy-makers to weigh the costs and benefits of each and consider making strategic choices between them. In the process, it will also shed light on how identity, strategy and policy actions interrelate.

\section{Role theory}

References to national roles are commonplace in foreign policy rhetoric. ${ }^{\text {I9 }}$ However, the concept is used to describe a range of behaviours, identities or status positions. ${ }^{20}$ The term derives from sociology and its core assumption is that participants in a social system adopt roles, rather like actors in a play, according to a script based on certain prescribed identities and behaviours. ${ }^{2 \mathrm{I}}$ Examples of roles in the British foreign policy lexicon might include 'bridge', 'pivotal power', 'beacon of democracy' or 'reliable ally' of the United States. ${ }^{22}$ Saying these roles are 'prescribed' could give the impression that policy is structurally determineda view seemingly reinforced on a material basis by Naomi Wish's suggestion that 'a nation's foreign policy behaviour is in large measure a product of its national capabilities or attributes. ${ }^{23}$ Yet Wish actually intends to convey a more circular

I6 BBC, 'Viewpoints: what should the UK's future global role be?', 24 Sept. 20I3, http://www.bbc.co.uk/news/ uk-24202354; Editorial, 'The UK's world role: Great Britain's greatness fixation', Guardian, 25 Jan. 20Io, http:// www.theguardian.com/commentisfree/20Io/jan/25/britain-world-role-europe-us, both accessed Io April 2014.

${ }^{17}$ For a critique of the search for a national role, see Christopher Hill, 'Britain's elusive role in world politics', British Journal of International Studies 5: 3, Oct. 1979, pp. 248-59. For an excellent defence of role theory, see Cameron G. Thies, 'Role theory and foreign policy', unpublished paper, May 2009, http://myweb.uiowa. edu/bhlai/workshop/role.pdf, accessed ro April 2or4.

I8 Jack Holland, Selling the war on terror: foreign policy discourses after 9/11 (London: Routledge, 20I2).

19 Cristian Cantir and Juliet Kaarbo, 'Contested roles and domestic politics: reflections on role theory in foreign policy analysis and IR theory', Foreign Policy Analysis 8: I, 20I2, p. I8.

20 Philippe G. Le Pestre, ed., Role quests in the post-Cold War era: foreign policies in transition (London: McGillQueen's University Press, 1997). Le Pestre cites at least six distinct applications of the concept, including role as a contribution or function (e.g. the US role in the Middle East peace process), as an influence or impact (e.g. Russia's role in negotiating an alternative to conflict with Syria in 2013), as 'expected behaviour based on certain rules' (akin to norms), as a part in a larger script or course of action, as policy decisions, or as rank/ status (p. 4). In using the term 'role theory', I am not denying the plurality of voices within this branch of enquiry, simply selecting the categories most useful to analysing the strategic choices facing the UK.

${ }^{2 \mathrm{I}}$ Lisbeth Aggestam, 'Role theory and European foreign policy: a framework of analysis', in Ole Elgstrom and Michael Smith, eds, The European Union's roles in international politics (London: Routledge, 2006), p. I2.

${ }^{22}$ See Oliver Daddow and Jamie Gaskarth, eds, British foreign policy: the New Labour years (Basingstoke: Palgrave, 20II), pp. I3-I6.

${ }^{23}$ Naomi B. Wish, 'National attributes as sources of national role conceptions', in Stephen G. Walker, ed., Role theory and foreign policy analysis (Durham, NC: Duke University Press, 1987), p. 96. This belief is apparent in a British context in the continual emphasis on Britain's island geography as imbuing the national consciousness 
Jamie Gaskarth

\section{Figure I: Wish's role cycle}

National material attributes

National role conceptions
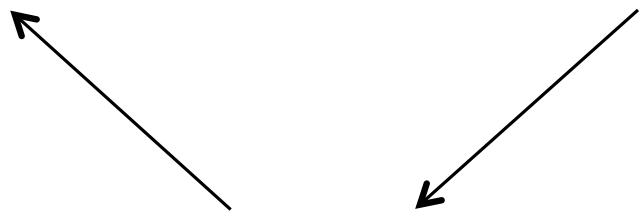

Foreign policy behaviour

process, in which material attributes feed into conceptions of national roles in a way that then shapes behaviour, which in turn affects national attributes (see figure I).

Indeed, one of the primary benefits of a role-based approach to foreign policy analysis is that it gives a more nuanced and dynamic account of identity formation and policy behaviour than purely individualist or structuralist accounts. Roles come with expectations about behaviour that shape actions. These role expectations or 'role prescriptions' derive from a state's membership of institutions and its interactions with external actors and domestic audiences, and condition what policies are deemed appropriate and how they are received. ${ }^{24}$ For instance, at the institutional level, membership of NATO prescribes the role of 'reliable ally' when a fellow NATO member is attacked; interactions with other states may lead to the role of 'bridge' or 'mediator'; domestic political groups might call for either withdrawal from global commitments, towards the role of 'isolate', or for the state to be a more active 'defender of the faith' or 'liberator' in support of domestic values. ${ }^{25}$ Governments that deviate from the 'script' can face punishment or at the very least confusion from domestic audiences or other international actors. Yet there is also scope for policy-makers to be creative in their choice of roles and how they interpret or enact them. ${ }^{26}$ Consequently, role theory provides for agency in foreign policy, even as it recognizes that it is bounded by social expectations.

As role theory has developed, analysts have devised a complex understanding of how this concept can be used to trace the policy-making process. At the broadest level of a state's disposition towards its external environment, Margaret Hermann describes 'role orientations' that provide an overarching rationale and pattern to how states interact with others. ${ }^{27}$ The examples offered are: expansionist, active

with a sense of separation from the continent: see e.g. L. Colley, Britons: forging the nation, 1707-1837 (London: Pimlico, I994), p. I7.

${ }^{24}$ Aggestam, 'Role theory and European foreign policy', pp. I4-18.

${ }^{25}$ These role conceptions are derived from Kal Holsti, 'National role conceptions in the study of foreign policy', International Studies Quarterly I4: 3, I970, pp. 233-309.

${ }^{26}$ Elgstrom and Smith, 'Introduction', in Elgstrom and Smith, eds, The European Union's roles, p. 5.

${ }^{27}$ In the original framework, Hermann is discussing how individual statespeople orient themselves to the international realm; however, since many of the subjects were autocratic leaders, their personal orientations were, by extension, those of the state. This article transfers the concept from individuals to the UK as a state actor, encompassing both individuals and the governments to which they belong. 
independent, influential, mediator/integrator, opportunist, developmental. ${ }^{28}$ To this list might be added the role of isolate. Underlying each is a different primary goal or driver; these are, respectively, power; autonomy; influence in the international system; solutions to problems; popular approval; the development of the state; and isolation. ${ }^{29}$ Status is an important underlying factor to all these orientations - either as an ultimate goal (states might crave power or influence to achieve or maintain a high status ${ }^{30}$ ) or as a source of social expectation (Great Powers might see being influential or a mediator as their duty because of their elevated status in international society). ${ }^{3 \mathrm{I}}$

The concept of role orientation is vital to our discussion since it represents the highest order of strategic thinking in foreign policy. It raises the question: what role orientation does the UK want to adopt, given the economic pressures it faces and the emergence of rival powers in the international system? Since role orientation is closely linked to social structures, and is the ultimate expression of how a state interacts with the system, it would seem to be a particularly difficult level at which an actor could exercise agency. Material constraints (national capabilities and relative power) as well as social structures (status and social interactions) combine to narrow the available choices. ${ }^{32}$ Switzerland cannot simply choose an expansionist role orientation. The United States would struggle to achieve isolation, given the volume of its trade and interactions abroad. Nevertheless, role theorists have noted that policy-makers do have the opportunity to alter their role orientation provided the social and material constraints allow it. ${ }^{33}$

The way governments pursue role orientations is by making choices from a range of more specific national role conceptions. The use of the term 'choice' is not intended to imply that this is always a deliberative process. The choice may at times be made for the policy-maker by social expectations. In his 1954 Reith Lectures, Oliver Franks confidently predicted that Britain would continue to be a Great Power, not as a result of 'reflection' and a 'conscious decision'; rather, he suggested that: 'It is part of the habit and furniture of our minds: a principle so much one with our outlook and character that it determines the way we act. ${ }^{34}$ Examples of national role conceptions include 'balancer', 'defender of the faith',

${ }^{28}$ Margaret G. Hermann, 'Foreign policy role orientations and the quality of foreign policy decisions', in Walker, ed., Role theory and foreign policy analysis, p. I34.

${ }^{29}$ Hermann, 'Foreign policy role orientations', p. I34.

${ }^{30}$ In his analysis from 1997, Alex Macleod argued that 'the search for status still dominates the formulation of Britain's international role conceptions': 'Great Britain: still searching for status?', in Le Pestre, ed., Role quests in the post-Cold War era, p. I62.

${ }^{3 \mathrm{I}}$ See Ian Clark, 'Towards an English School theory of hegemony', European Journal of International Relations I5: 2, 2009, p. 2I2.

32 As Wish notes: 'Decision makers from large nations, in contrast to small ones, have a greater felt need to influence international affairs on a wider range of issues'; similarly, 'Decision makers from nations that are more economically developed ... perceive larger domains of national influence': Wish, 'National attributes', pp. 97-8.

33 Chih-yu Shih, 'National role conception as foreign policy motivation: the psychocultural bases of Chinese diplomacy', Political Psychology 9: 4, I998, pp. 602-603. A prominent example is the United States' transformation from 'isolated' to 'influential' role orientation during and after the Second World War. Arguably, China is moving from a 'developmental' role orientation to either 'active independent' or 'influential'.

34 Oliver Franks, 'Britain and the tide of world affairs': Reith Lectures, BBC Home Service, 7 Nov. 1954, http:// downloads.bbc.co.uk/rmhttp/radio4/transcripts/I954_reithI.pdf, accessed Io April 2014 . 
'leader' or 'reliable ally', among others. ${ }^{35}$ Role orientations are made up of 'role sets' or groups of such conceptions. ${ }^{36}$ Yet no single role orientation will encompass all national role conceptions. That means there is always scope for reorientation if the pattern of conceptions shifts.

The fact that role conceptions might point to different identities or policies also raises the prospect of role conflict. Rather than a purely negative process, role conflict can actually provide a mechanism for change in foreign policy and so is seen as a useful means of ensuring that policy evolves and is appropriate to the specific policy environment. ${ }^{37}$ However, conflicts can have damaging consequences for policy and reputation if either internal or external actors reject one role in favour of another in a very public fashion. This highlights the importance of role performance or 'role enactment'. ${ }^{38}$ Narrowing the analysis still further from the abstract to the empirical, role theorists examine how these conceptions are performed through particular policy choices and outputs - and how these are received. This process represents a powerful feedback loop, shaping the expectations of others in a way that could have an impact on future role orientations or national role conceptions.

For illustrative purposes, I explore the role orientation of Britain as an influential actor in the international system in figure 2 below. The list of national role conceptions is not exhaustive: many others might have been added (e.g. regional protector, example to others, liberator). Each could in some way be expected to afford the UK influence over other international actors, but none automatically translates into favourable outcomes. For example, being a generous aid donor could enhance the UK's identity as a positive influence on global development; but if British policy-makers sought to exploit this for political or economic advantage, then others might object to that role as neo-colonialism or cynical self-interest. ${ }^{39}$ In other words, this list of role conceptions and performances also contains within it the seeds of potential role conflict.

Clearly, then, this is not a closed system but a dynamic process of interpretation, interaction and contestation that does not automatically relate roles to outcomes in a linear way. Nevertheless, in outlining a role orientation, as well as the role conceptions and performances that flow from it, we begin to understand

35 For a list of potential role conceptions, see Holsti, 'National role conceptions', pp. 296-7.

${ }^{6}$ Stephen G. Walker and Sheldon W. Simon, 'Role sets and foreign policy analysis in Southeast Asia', in Walker, ed., Role theory and foreign policy analysis.

${ }^{37}$ James G. Rosenau, 'A pre-theory revisited: world politics in an era of cascading interdependence', International Studies Quarterly 28: 3, 1984, p. 270.

${ }^{8}$ Cameron G. Thies, 'International socialization processes vs. Israeli national role conceptions: can role theory integrate IR theory and foreign policy analysis?', Foreign Policy Analysis 8: I, 20I2, pp. 25-46.

39 A recent example of this might be the attempt by Andrew Mitchell, Development Secretary from 2010 to 20I2, to portray aid to India as useful in securing defence contracts. Similarly, being a reliable ally of the US, through intelligence-sharing and military cooperation, is often perceived to bring influence: see Tony Blair, A Journey (London: Hutchinson, 20IO), p. 4IO; Jack Straw, Last man standing (Basingstoke: Macmillan, 20I2), p. 37I. But, aligning oneself so closely with a state alleged to have broken international law and violated human rights has also led to charges of British complicity that have had negative impacts on the UK's influence, particularly in Islamic countries: see e.g. Jamie Gaskarth, 'Entangling alliances? The UK's complicity in torture in the global war on terrorism', International Affairs 87: 4, July 20II, pp. 945-64; Ruth Blakeley, State terrorism and neoliberalism: the North in the South (Abingdon: Routledge, 2009). 


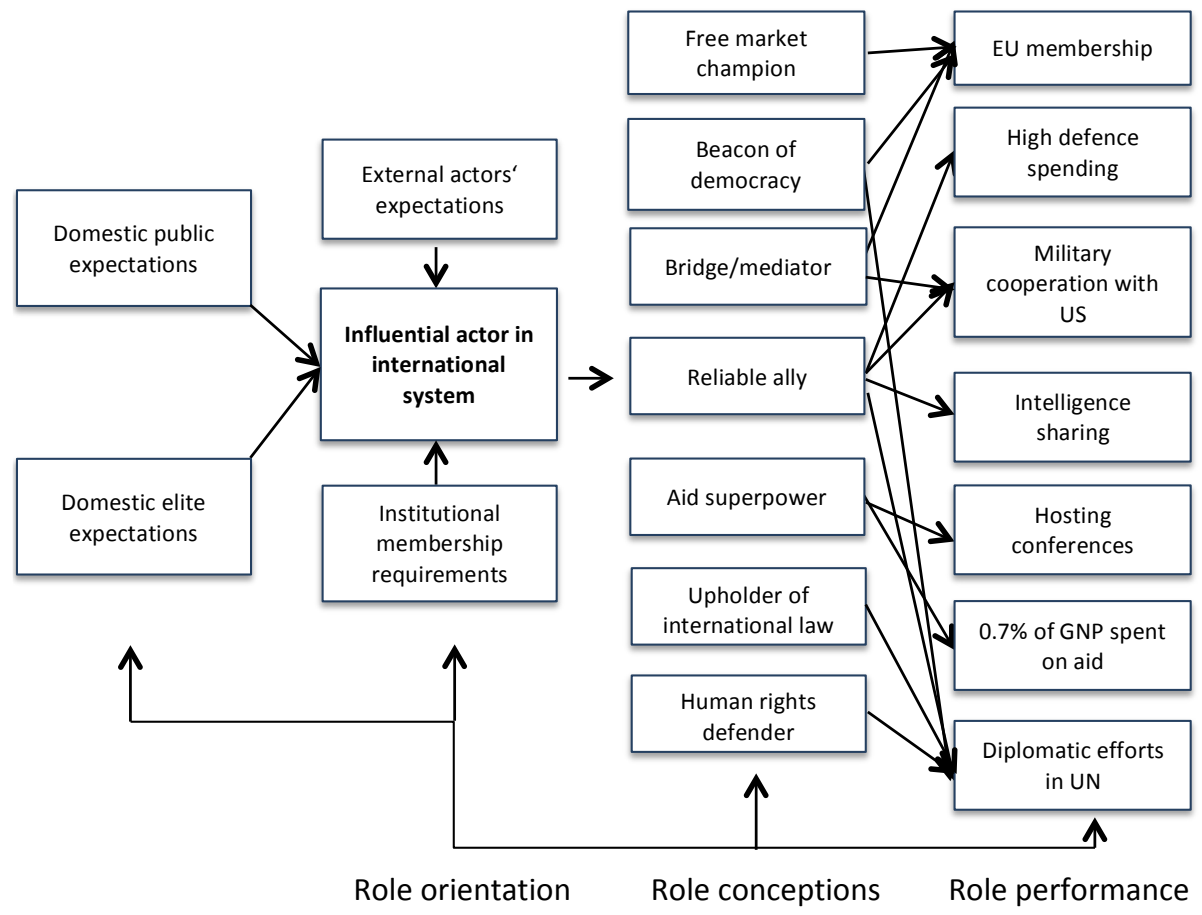

Note: In devising this chart, the author has adopted the formulation in Aggestam, 'Role theory and European foreign policy' to include insights from the various authors in Walker, Role theory and foreign policy analysis.

policy identities and behaviour in a more strategic manner. The next step for this article is to ask whether policy-makers could make a strategic choice as to which role orientation they adopt in order to further their national values.

Role theorists have tended to be cautious about the level of deliberate agency policy-makers can exercise when it comes to role-making and role-taking. ${ }^{4}$ Lisbeth Aggestam asserts that acknowledging scope for agency 'does not mean that we consider roles to simply be like hats that you can take on and off'. ${ }^{4}$ Nevertheless, as stated above, role orientations do change and policy-makers, as key interpretative actors, can contribute to shifts in understanding. As Martin Hollis and Steve Smith note, foreign policy-makers are sometimes able to achieve a level of 'role distance'- that is, to find space to reflect on and interpret what roles are available and how they should be performed..$^{42}$ Therefore, it does not

$4^{\circ 0}$ For an exploration of these two concepts, see Sebastian Harnisch, 'Conceptualizing in the minefield: role theory and foreign policy learning', Foreign Policy Analysis 8: I, 20I2, pp. 47-69.

4I Aggestam, 'Role theory and European foreign policy', p. I8.

${ }^{42}$ Martin Hollis and Steve Smith, 'Roles and reasons in foreign policy decision making', British Journal of Political Science I6: 3 , 1986, pp. 269-86. This is not to assume that policy-makers can adopt an 'objective' position. As Hollis and Smith put it (p. 277): 'Role-distance can be thought of not as standing outside the play but as detached judgement within it.' 
seem unreasonable to suggest that there exists the scope for British foreign policymakers to examine the range of potential role orientations available to a state such as the UK and explore the likely benefits and costs of each.

What follows is a preliminary investigation into six such role orientations that feature prominently in recent debates over British foreign policy. These are: isolate, regional partner, influential (rule of law state), thought leader, opportunistinterventionist, and Great Power. In providing a preliminary sketch of each, I aim to offer a more useful platform for discussion on role orientation than the limited debate on whether the UK should align itself with the United States or Europe. In the process, I also aim to give a sense of the different policy directions that result from choices about role orientation.

\section{Isolate}

The 'isolate' role orientation is inward-looking, and involves expending as little energy and resources externally as necessary to allow states to focus on domestic concerns. ${ }^{43}$ In the British context, this image is usually evoked and then summarily dismissed. For example, Franks noted: 'There are some who suggest that the ... thing to do is to withdraw from world affairs and lead a quiet life on our island, democratic, contented, and reasonably industrious', a position which he described as 'impossible'. ${ }^{44}$ Throughout Britain's history, there have been voices calling for the country to adopt a more circumspect, non-interventionist stance on particular regional or global issues. This 'dissenting tradition' commonly saw foreign policy as a conspiracy run by the aristocratic class. ${ }^{45}$ However, it was more often military intervention than involvement in international affairs per se which raised objections. ${ }^{46}$

In the mid-nineteenth century, non-intervention was championed by the Manchester school of John Bright and Richard Cobden, two members of the British parliament. Bright protested against alliances with foreign powers as leading to 'a system which binds us in all these net-works and complications, from which it is impossible we gain one single atom of advantage'. ${ }^{47}$ Bright's fellow radical MP Richard Cobden launched a 'no foreign politics' campaign, which he asserted would 'comprise every representative of our manufacturing and commercial districts'. ${ }^{48}$ This was designed to subvert the conduct of foreign

43 See Naomi B. Wish, 'Foreign policy makers and their national role conceptions', International Studies Quarterly 24: 4, I980, p. 538 .

${ }^{44}$ Franks, 'Britain and the tide'. Similarly, the 1998 Strategic Defence Review acknowledged: 'We could of course as a country, choose to take a narrow view of our role and responsibilities which did not require a significant military capability ... This is indeed a real choice' (MoD, Strategic Defence Review, London: The Stationery Office, I998, p. 23). But in the same paragraph, without elaboration, it decided this was 'not one the Government could recommend for Britain'.

45 A. J. P. Taylor, The troublemakers (London: Hamilton, I957).

${ }^{4}$ Even so, this did not stop the dissenters from advocating intervention abroad on occasion: see Taylor, The troublemakers, pp. 33, I89.

47 John Bright, 'Principles of foreign policy', reproduced in Edgar Jones, ed., Selected speeches on British foreign policy 1738 to 1914 (UK: Kessinger Publishing, 2006), p. I94.

$4^{8}$ Richard Cobden, 'England', in John Bright, ed., Political writings of Richard Cobden (London: Cassell, I886), p. 34. 
policy-making by elites and argued for 'as little intercourse as possible between governments. ${ }^{49}$ This is perhaps the nearest that British politics has come in the last two centuries to a movement advocating a non-internationalist role for the UK.

More recently, a growing public scepticism about the UK's international duties is apparent in the fallout from the 2003 Iraq War and the 2008 financial crisis. In a 2009 poll, 5 I per cent of the public disapproved of the UK's military involvement in Afghanistan and 57 per cent felt that the UK would not benefit from its actions there. ${ }^{50}$ In April 2oII, 50 per cent of the British public polled disapproved of intervention in Libya, with only 23 per cent approving - despite the limited nature of the operation..$^{\text {II }}$ Opinion polling on intervention in the last two decades suggests that public support for military action can wane dramatically when casualties are considered. ${ }^{52}$ Similarly, support for development aid has declined as government budgets have been tightened, with those favouring an increase falling from 49 per cent to 35 per cent between 2008 and 20IO, and 66 per cent believing the UK gave too much aid. ${ }^{53}$ This could hint at an emerging discourse in favour of isolation. In sum, a policy of reduced global commitment, particularly in respect of military action, would seem to be garnering public approval.

In its favour would be the immense financial savings to be had. Keith Hartley has estimated that Britain's role as a global military actor costs around I per cent of GDP, equivalent to an annual price tag of $\mathcal{E}_{\mathrm{I}} \mathrm{s}$ billion. ${ }^{54}$ The UK's involvement in Iraq between 200I and 20I0 is reckoned to have cost $£ .9 .24$ billion,,$^{55}$ and its Afghanistan campaign, $f_{2} 5$ billion to May 2013. ${ }^{56}$ At a time when public debt is at unprecedented levels and major cuts to public services are being implemented, this is an unusually propitious time to argue for a more isolated role orientation for the UK in the international arena. A focus on economic prosperity and more productive non-military industrial activity would be likely to attract public support.

However, the national role conceptions that might support a shift like this are sparse. The UK has been a prominent international actor for such a long time that there are few 'scripts' for an isolated UK that policy-makers can enact. By contrast, the national role conceptions of the UK as 'influential', through being a 'reliable ally' and 'upholder of international law', are recurrent themes. ${ }^{57}$ Cutting the defence budget substantially would imperil the UK's relationship with the US-a

49 Cobden, 'England', p. 34.

so Jason Reifler, Harold D. Clarke, Thomas J. Scotto, David Sanders, Marianne C. Stewart and Paul Whiteley, 'Prudence, principle and minimal heuristics: British public opinion toward the use of military force in Afghanistan and Libya', British Journal of Politics and International Relations I6: I, 20I4, pp. 28-55.

SI Reifler et al., 'Prudence'.

52 See Jamie Gaskarth, British foreign policy (Cambridge: Polity, 20I3), p. 78.

53 Gaskarth, British foreign policy, p. II8.

54 Keith Hartley, 'The economics of the Defence Review', The RUSI Journal I55: 6, 20I0, p. 5.

55 BBC, 'Iraq War in figures', I4 Dec. 20II, http://www.bbc.co.uk/news/world-middle-east-IIIO7739, accessed Io April 20I4.

${ }_{56}^{6}$ Richard Norton Taylor, 'Afghanistan war has cost Britain more than £37bn, new book claims', Guardian, 30 May 2013, http://www.guardian.co.uk/world/2013/may/3o/afghanistan-war-cost-britain-37bn-book. £25 billion is the MoD estimate.

57 Hew Strachan, 'The strategic gap in British defence policy', Survival 5I: 4, 2009, p. 5I; Chris Kitchen and Rhiannon Vickers, 'Labour traditions of international order and the dilemma of action towards Iran', British Journal of Politics and International Relations I5: 2, 2013, pp. 299-316. 
cornerstone of British strategic thinking since the Second World War. It would also cause friction with European neighbours, since it might threaten the future of NATO, as well as European defence initiatives that have been led by the UK and through which the UK has been able to express the national role conceptions of 'regional leader' and 'positive European partner'. Although successive defence reviews, from the 1998 Strategic Defence Review to the 2008 National Security Strategy (NSS) and 20I0 SDSR and updated NSS, have suggested that 'there is today no direct military threat to the United Kingdom or Western Europe', ${ }^{8}$ the US pivot to Asia, combined with a UK adoption of the isolate role, might lead to a revival of regional security threats. ${ }^{59}$ Russia's actions in Georgia and Ukraine remind us that some states see military force as a viable tool for achieving foreign policy aims.

Moreover, even those discourses that at first glance seem to imply isolationism often in reality support an internationalist orientation. Cobden may have been critical of government-to-government interaction, but he also called for 'as much connexion as possible between the nations of the world' ${ }^{60}$ In doing so, he was advocating not isolation, but rather the development of people-to-people networks on an informal and hence non-governmental basis. Underlying this attitude was a belief that trade and human contact would spread peace. ${ }^{\text {6I }}$ Similarly, more recent dissent over Britain's membership of the European Union is usually framed as a desire not for isolation but rather for withdrawal from a role orientation of 'regional power' towards a more internationally influential role via trade with the wider world. ${ }^{62}$

In other words, despite appearances, advocating a role orientation of isolate is unlikely to accord with the traditions and beliefs of the British public, or their elites. ${ }^{6}$ There is also the question of practicality: how feasible would it be for the UK to pursue a policy of isolation, given its membership of so many international organizations and treaty arrangements? ${ }^{64}$ The fallout from Britain's reversing its involvement in NATO, the UN, the EU or, to a lesser extent, the Commonwealth would be severe. Overall, any effort to pursue a truly radical non-interventionist stance would face challenges not only from the militarist groups in British society but also from those in favour of regional integration and/or international organizations, human rights and global civil society activists, and multinational firms pursuing a globalist agenda. In short, there is unlikely to be enough political or

${ }^{8}$ MoD, Strategic Defence Review, p. 9; Cabinet Office, National Security Strategy (London: TSO, 2008), p. 3.

59 Michael Rühle, 'The future of the transatlantic security relationship', American Foreign Policy Interests 35:5, 2013 , pp. $283-7$.

60 Cobden, 'England', p. 34 .

6I Cobden, 'England', p. 36 .

${ }^{62}$ In his 2013 speech to his party's conference Nigel Farage, the UKIP leader, asserted: 'Only by leaving the union can we regain ... our ability to trade freely with the fastest-growing economies in the world', and described party members as 'Open to the world. The opposite of insular': http://blogs.spectator.co.uk/ coffeehouse/2013/og/nigel-farages-speech-full-text-and-audio/, accessed io April 2014.

${ }_{3}$ Both Cobden and Bright lost their parliamentary seats in I857 as a result of their anti-war stance: see Douglas Hurd and Edward Young, Choose your weapons (London: Weidenfeld \& Nicolson, 20Io), p. IIo.

${ }^{6}$ According to the FCO website, the UK is involved in over I4,000 treaty arrangements: https://www.gov.uk/ uk-treaties, accessed ro April 2014 . 


\section{Figure 3: Isolate role play}

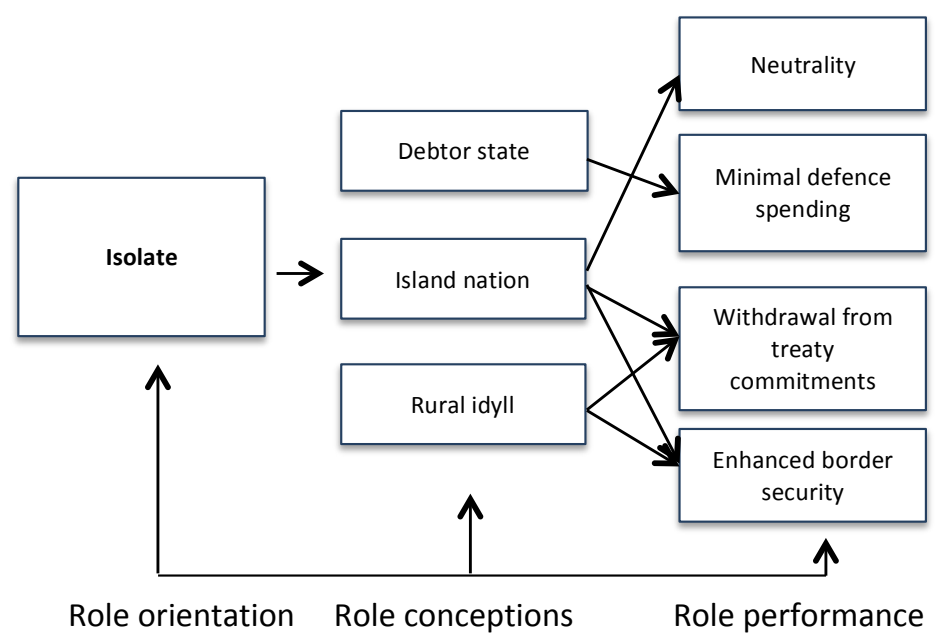

social force to carry it through. Despite this, it is worth raising as a potential role orientation, if only to highlight the limits to policy-makers' choices given the existence of longstanding alternative orientations premised on the idea of the UK as an active participant in international affairs.

\section{Regional partner ${ }^{65}$}

Given the economic crises that have affected the eurozone in recent years, combined with the political tensions in the EU over how to respond, it may seem strange to consider a role orientation that aligns the UK more closely with Europe. The rhetoric on all parts of the political spectrum in the UK is about renegotiation of Britain's relationship with the EU to repatriate powers. Politicians want to reassert the UK's autonomy from the forces of European integration and many seek a referendum to decide whether Britain's membership of the Union should continue. Nevertheless, a role orientation that posits the UK as a regional rather than a global power has to be considered in the light of the rise of alternative centres of power in Asia and South America. At the end of the Cold War, a number of commentators advocated rejecting what they saw as the illusion of Britain as a Great Power with an international role in favour of an acceptance that the UK's power had declined. ${ }^{66}$ Rather than cling to the coat-tails of the United States, an often capricious ally, Britain had to embrace its historical European identity and play a fuller leadership role in Europe. As a result, Britain would be able to have a more meaningful influence on events than it could in isolation or as a transatlantic groupie of the US.

${ }^{65}$ Hermann originally termed this orientation 'regional collaborator' (Hermann, 'Foreign policy role orientations'). However, in recognition of the historical connotations of the word 'collaborator' in the European context, I here use 'partner' instead.

${ }^{66}$ William Wallace, 'British foreign policy after the Cold War', International Affairs 68: 3, Autumn 1992, pp. 423-42; Hugo Young, This blessed plot (London: Macmillan, 1999); Will Hutton, 'Britain in a cold climate: the economic aims of foreign policy in the I990s', International Affairs 68: 4, Winter 1992, pp. 619-32. 
British foreign policy-makers have periodically made efforts to put forward a national role conception of the UK as a longstanding European state. As foreign secretary, Jack Straw asserted: 'We are a European nation, and always have been. Our monarchy was Danish, then Norman, then Dutch, then German. ${ }^{67}$ For Straw, it was engagement with Europe that led to the UK's international role in the first place. This narrative can be seen as flowing from a wider revisionist effort in academic circles during the I990s to reconnect British history with its European past. ${ }^{68}$ But, as Timothy Garton Ash has noted, even though the material exists to create a European identity for Britain, "it cannot be the identity ... The other identities are too strong. ${ }^{, 69}$ In particular, the UK populace continue to associate themselves more with English-speaking countries, especially Australia, Canada and New Zealand, than with their European neighbours. ${ }^{70}$ Resistance to a regional orientation, and to a national role conception of Britain as European, is powerfully reinforced in public discourse by media images of the continent as a source of 'un-British' systems of government and laws as well as security threats from immigration. ${ }^{7 \mathrm{I}}$ Despite the potential advantages in terms of regional and global influence that could flow from the UK's embracing an orientation towards Europe, these seem to be counteracted by other orientations and conceptions that emphasize separation and distance.

There is also a question mark over how far other EU member states would accept the UK's playing a more integrated part in decision-making. The UK often enacts the role of 'awkward partner' in a European context that is useful to other states in a number of ways. ${ }^{72}$ When Britain opposes more EU regulation or political integration, it advances the argument for a more diverse form of community based on liberal economic principles. Other states that share this vision can leave the UK to suffer the political cost of being labelled 'awkward' and present their own concerns as reasonable in contrast to UK intransigence. Meanwhile, those favouring integration can dismiss alternative visions of Europe as Euroscepticism along British lines. Furthermore, depending on the direction in which the UK wished to take the European Union, a more regional role orientation could alienate either France and Germany - if the UK were seen as muscling in on their traditional leading partnership — or the other member states - if a troika of France, Germany and the UK were seen as dominating the community. This reminds us that regional and international societal expectations about roles might hamper efforts to change a country's orientation.

${ }^{67}$ Jack Straw, 'Pursuing an active and engaged foreign policy', speech in the House of Commons, London, 22 June 200I: Hansard (Commons), vol. 370, cols 28I-29I.

68 Timothy Garton Ash, 'Is Britain European?', International Affairs 77: I, Jan. 2000, pp. I-I3.

69 Garton Ash, 'Is Britain European?', p. I3.

${ }^{\circ}$ Chatham House/YouGov survey, British attitudes towards the UK's international priorities (London: Chatham House, July 20Io), p. 2.

${ }^{71}$ Oliver Daddow, Britain and Europe since 1945: historiographical perspectives on integration (Manchester: Manchester University Press, 2004); Anthony Forster, Euroscepticism in contemporary British politics (London: Routledge, 2002).

72 Stephen George, The awkward partner: Britain in the European Community (Oxford: Oxford University Press, 1998). 


\section{Figure 4: Regional partner role play}

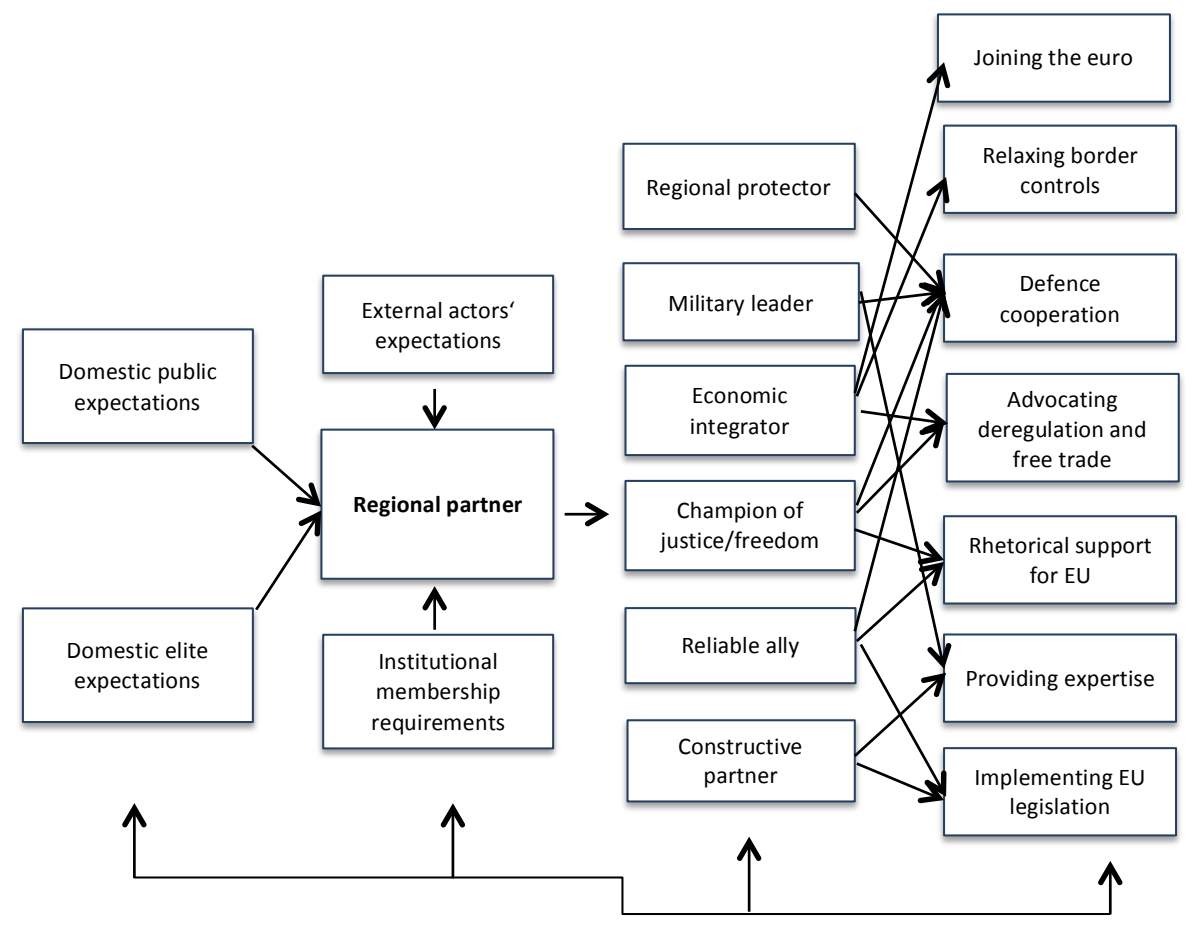

Role orientation Role conceptions Role performance

\section{Influential (rule of law state)}

The next role orientation the UK might pursue is that of being an influential power, with an emphasis on the national role conception of being an upholder of international law. Since the UK already has a high status in global politics, via its institutional memberships and relative prosperity, it clearly benefits from the existing arrangement of international society. It could therefore carve out a niche for itself as a constructive member of that society wishing to preserve the status quo. The role of being a status quo power has been at the core of Britain's self-identity for centuries. The nineteenth-century German Chancellor Otto von Bismarck described Britain as one of les satisfaits, ${ }^{73}$ a state that was happy with its position in world affairs and would not seek radical reform of the prevailing international order. In his famous 1907 memorandum, Sir Eyre Crowe asserted that: 'England, more than any other non-insular Power, has a direct and positive interest in the maintenance of the independence of nations. ${ }^{74}$ Given its imperial past and recent interventionism, other states could justifiably critique the idea of Britain

73 D. C. M. Platt, Finance, trade, and politics in British foreign policy, 1815-1914 (Oxford: Clarendon Press, 1968), p. 354.

74 Eyre Crowe, 'Memorandum on the present state of British relations with France and Germany', I Jan. I907, http://en.wikisource.org/wiki/Memorandum_on_the_Present_State_of_British_Relations_with_France_ and_Germany, accessed I3 April 2014. 
as a longstanding supporter of the norms of sovereignty and non-intervention so central to international law (and order). However, this role conception proved useful in providing a rationale for the UK's involvement in both world wars, the Korean War in 1950 and the Falklands War in $1982 .{ }^{75}$

In addition, the idea of upholding international law and preserving the essential character of the states-system is likely to be attractive to other actors, such as the rising powers of Brazil, China and India. These states are very protective of the norms of sovereignty and non-intervention, particularly when it comes to their own national values and interests. UK support for liberal interventionism and preventive war has caused concern in these quarters. This reminds us that choosing between role orientations, and their underlying national role conceptions, should involve consideration of how such choices will be received by the wider international community. If Britain is to exert influence in the coming decades, it will increasingly have to co-opt the rising powers into accepting British assumptions about policy priorities and appropriate forms of action. Emphasizing national role conceptions for the UK that accord with their values, such as 'status quo power', 'upholder of international law' or 'multilateralist', would help to facilitate these relationships.

The role performances that might flow from these conceptions include doing the basics of international diplomacy: drafting papers and legal treaties, hosting conferences, conducting observer missions, verifying commitments and offering expertise. These are already acknowledged as being particular strengths of British foreign policy. Lord Malloch-Brown has suggested that despite the furore over its involvement in the 2003 Iraq invasion, Britain was still seen in the UN as 'in all other ways, very active - with all the first-class ambassadors and first-class staff in New York, sending some of our best diplomats, you know just working the UN with a seriousness that, say, the US didn't do'. ${ }^{76}$ This is also a role that fits with Britain's self-identity as being a constructive member of international society. A commitment to multilateral institutions has been a mainstay of a number of British strategy documents over the past decade. ${ }^{77}$ In its 2012 annual report, the FCO boasts that: 'The UK continues to believe that a rules-based system is the best way to promote British interests ... The FCO has been active in ensuring that international institutions are effective. ${ }^{78}$ One could imagine the UK playing a useful part in international society by providing diplomatic expertise and financial support for the institutions of global governance - and, in the process, moving away from the more militaristic role performances of recent decades.

75 David M. McCourt, 'Role-playing and identity affirmation in international politics: Britain's reinvasion of the Falklands, 1982', Review of International Studies 37: 4, 20II, pp. I599-62I.

${ }^{76}$ Interview with the author, 2010.

77 See e.g., FCO, UK international priorities (London: TSO, 2003), p. 24; Cabinet Office, National Security Strategy (2008), pp. 9, 47; Cabinet Office, A strong Britain in an age of uncertainty: National Security Strategy of the UK, Cmd 7953 (London: TSO, 2010), p. Io.

${ }^{78}$ FCO, Annual report and accounts 2011-12 (London: TSO, 2012), p. 4. Evans and Steven assert: 'Britain already excels at the nuts and bolts of foreign policy. Few governments are better at coordinating a UN Security Council Resolution or a summit communiqué, at getting candidates into senior international jobs, or at the day-to-day work of managing bilateral relationships or administering aid spending': Alex Evans and David Steven, Organizing for influence: UK foreign policy in an age of uncertainty (London: Chatham House, 20Io), p. I5. 
However, maintaining the existing institutions of international law and society in aspic is not sustainable in the long term. For one thing, there are continuing calls for reform of key international organizations such as the World Trade Organization, the World Bank/IMF and the UN Security Council. Thus, being a status quo power and upholder of international law means, in practice, managing continual pressures for change. There is also the thorny question of when intervention is required to uphold the law. When Nicholas Wheeler and Tim Dunne advocated Britain's taking the role of 'good international citizen' in the I99os, they left open the possibility of transgressing international law to promote human rights. ${ }^{79}$ One could see here a straightforward role conflict between the role conceptions of 'human rights defender' and 'upholder of international law'; but it might also be interpreted as a conflict internal to the latter role, over whether international criminal law and human rights conventions should be upheld over legal norms of sovereignty and non-intervention.

In the past decade, there has been a great deal of controversy over what kinds of action are required to maintain the status quo of a rules-based international system. The UK's involvement in the Iraq conflict in 2003 was justified by Tony Blair on the basis that Saddam Hussein had breached I7 UN Security Council resolutions and that the credibility of international law and the UN system was at stake. ${ }^{80}$ Opposing this view among the permanent members of the Security Council were China, Russia and France, who felt that Iraq had been contained and did not pose an imminent threat to international peace and security. The political fallout from these conflicting interpretations of the role of "upholder of international law' was considerable.

The coalition government sought to resolve tensions over the use of force through an emphasis on achieving an international consensus in favour of action. Discussing intervention in Libya in 20II, Cameron defined his three essential criteria that would have to be met as a basis for action as: 'Demonstrable need. Regional support. And a clear legal basis. ${ }^{8 \mathrm{I}}$ The inclusion of regional support and a 'clear' legal position as vital factors was designed to distinguish this basis for decision from that applied in respect of Iraq in 2003. Through substantial diplomatic effort, the UK and its allies had been able to gain the approval (or acquiescence) of all the permanent members of the UN Security Council, as well as that of the African Union and Arab League, for military action to halt the abuses of the Gaddafi regime. This appeared to signal a revival of the idea that intervention could be used for humanitarian purposes $^{82}$ — with the UK spearheading this initiative.

Yet in August 2013 the UK was again contemplating military action against the wishes of Russia, China and some regional actors, this time over Syria's use of chemical weapons. When two motions to act were opposed in the House of

79 Nicholas J. Wheeler and Tim Dunne, 'Good international citizenship: a third way for British foreign policy', International Affairs 74: 4, I998, pp. 847-70.

80 Tony Blair, motion for war, I8 March 2003, http://www.publications.parliament.uk/pa/cm200203/cmhansrd/ voo30318/debtext/30318-06.htm, accessed Io April 20I4.

8I 'Libya: David Cameron statement on UN resolution', I8 March 20II, http://www.bbc.co.uk/news/ uk-politics-I2786225, accessed ro April 2014.

82 Thomas G. Weiss, 'RtoP alive and well after Libya', Ethics and International Affairs 25: 3, 20II, pp. $287-92$. 
Figure 5: Influential (rule of law state) role play

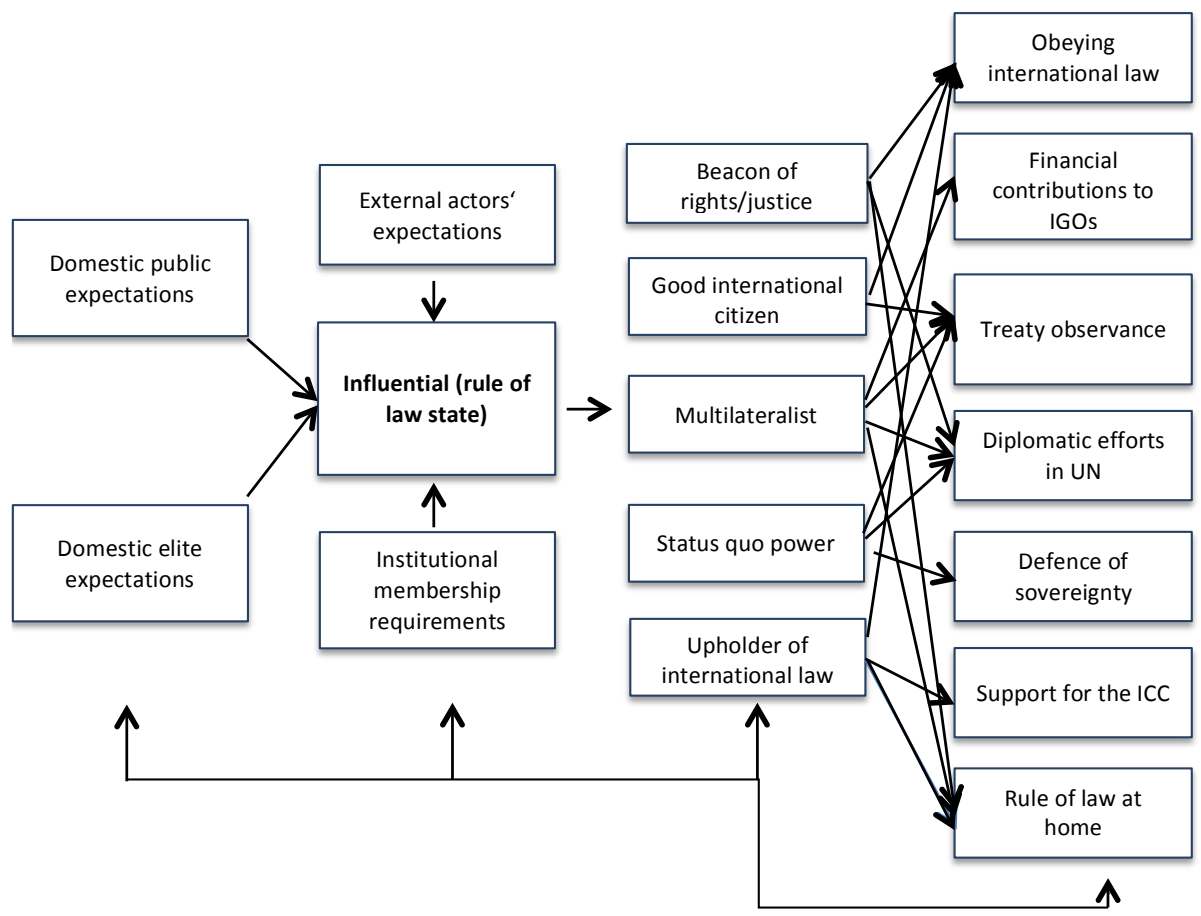

Role orientation Role conceptions Role performance

Commons, a brief flurry of debate emerged about what this would mean for Britain's influence in the world, with some seeing the parliamentary outcome as symptomatic of a retreat from the role orientation of 'influential' and national role conception of 'reliable ally' of the United States. ${ }^{83}$ Nevertheless, polls suggested a hardening of the public attitude against the use of force. ${ }^{84}$ When a subsequent deal was brokered between Russia and the US, encouraging Syria to relinquish its chemical weapons, the UK was sidelined by both parties as neither a likely military belligerent nor a mediator for peace. Therefore, we can see that trying to fulfil a role orientation that does not accord with the views of the British public - or key actors in the global arena- has profoundly negative consequences. If the UK government had stuck to its earlier requirements of a clear legal basis and regional support, this role conflict might have been avoided. Such consistency would also have provided greater clarity for allies in predicting when they could rely on UK support.

${ }^{83}$ See 'Syria crisis: "Britain shouldn't turn its back on world", says Osborne', Telegraph, 30 Aug. 20I3, http:// www.telegraph.co.uk/news/politics/georgeosborne/I0275655/Syria-crisis-Britain-shouldnt-turn-its-backon-world-says-Osborne.html; 'Is Paddy Ashdown right that Britain is now a "hugely diminished country"?', Guardian, 30 Aug. 2013, http://www.theguardian.com/world/poll/2013/aug/30/paddy-ashdown-syriacomments-poll, both accessed io April 20I4.

${ }^{84}$ Will Dahlgreen, 'Opposition to Syria intervention hardens', 4 Sept. 20I3, YouGov, http://yougov.co.uk/ news/20I3/o9/04/opposition-missile-strikes-69/, accessed Io April 20I4. Within a week, the proportion of those polled opposed to missile strikes against Syria rose from 50 per cent to 69 per cent. 


\section{Thought leader ${ }^{85}$}

A recent reappraisal of the UK's international position has argued that the UK should aspire to be a 'thought leader'. According to this logic, the UK's declining influence means that its capacity to respond to risks and shape outcomes in global politics will depend on whether other states and transnational actors can be persuaded to take action. As Alex Evans and David Steven put it, the UK will need to 'adopt and excel in the role of thought leader, recognizing that it will often have greater comparative advantage in this area than in the "endgame" on key risks, where larger powers will tend to dominate'. ${ }^{86}$ They see, in addition to providing creative thinking and actively promoting innovations in world politics, a supporting role for the UK in the thought leadership of others, 'acting as a convenor for debate, discussion and dialogue' ${ }^{87}$ On a practical level, the role of thought leader would involve creating shared awareness of risks, as well as shared platforms and operating systems to campaign for change and manage the risks identified.

How far this idea constitutes a role orientation in its own right, rather than a national role conception within the role set of the 'influential' orientation, is debatable. In a discussion on the concept at Chatham House, one of the contributors argued that thought leadership should be seen as 'part of a systematic shift in an approach to global affairs, not a tactical way to deliver in the national interest, because then you are instrumentalising again, and you can't align your forces around a kind of narrow definition of an interest. These are just bigger coalitions. ${ }^{98}$ This implies that thought leadership can be seen as a role orientation. Acting as a thought leader is about identifying risks and solutions that affect the international community as a whole. In this way, the UK would become a problem solver, working to further global public goods. While it would derive some kudos from drawing attention to problems and coordinating responses, the subsequent action would need to be in the group interest. This could provide an overarching orientation to policy-making. However, it would also be likely to contain the seeds of role conflict since, at times, self-interest would have to prevail.

That said, being a thought leader would seem to fit naturally with aspects of Britain's self-identity in world politics. The UK is a prominent norm entrepreneur. It was instrumental in creating an International Criminal Court in 1998 and supported a ban on landmines under the auspices of the Ottawa Treaty. It provided a platform for discussion on African development and debt relief via its presidency of the G8 in 2005 and has been at the forefront of efforts to elevate climate change as a major security issue. ${ }^{89}$ These activities have afforded the UK

${ }^{85}$ This role is similar to that of 'mediator-integrator' in Hermann's typology, an orientation in which policymakers are 'genuinely interested in seeing that problems are solved': 'Foreign policy role orientations', p. I38.

${ }^{86}$ Evans and Steven, Organizing for influence, p. I4.

${ }^{87}$ Evans and Steven, Organizing for influence, p. I4.

${ }^{88}$ Nick Mabey, 'The UK and the world: session 4', Chatham House, London, I3 July 20Io, p. Io, http://www. chathamhouse.org/sites/default/files/public/Meetings/Meeting\%2oTranscripts/I307Ioukrole_4.pdf, accessed I3 April 20I4.

${ }^{89}$ See Alex Evans, remarks in Alex Evans, David Steven and Robin Niblett, 'UK and the world: governing in an age of uncertainty', transcript of seminar, Chatham House, London 9 June 20I0, p. I8, http://www.chathamhouse. $\mathrm{org} / \mathrm{sites} /$ default/files/public/Meetings/Meeting\%20Transcripts/o90620Ioalexevansetal.pdf, accessed I3 April 20I4. 


\section{Figure 6: Thought leader role play}

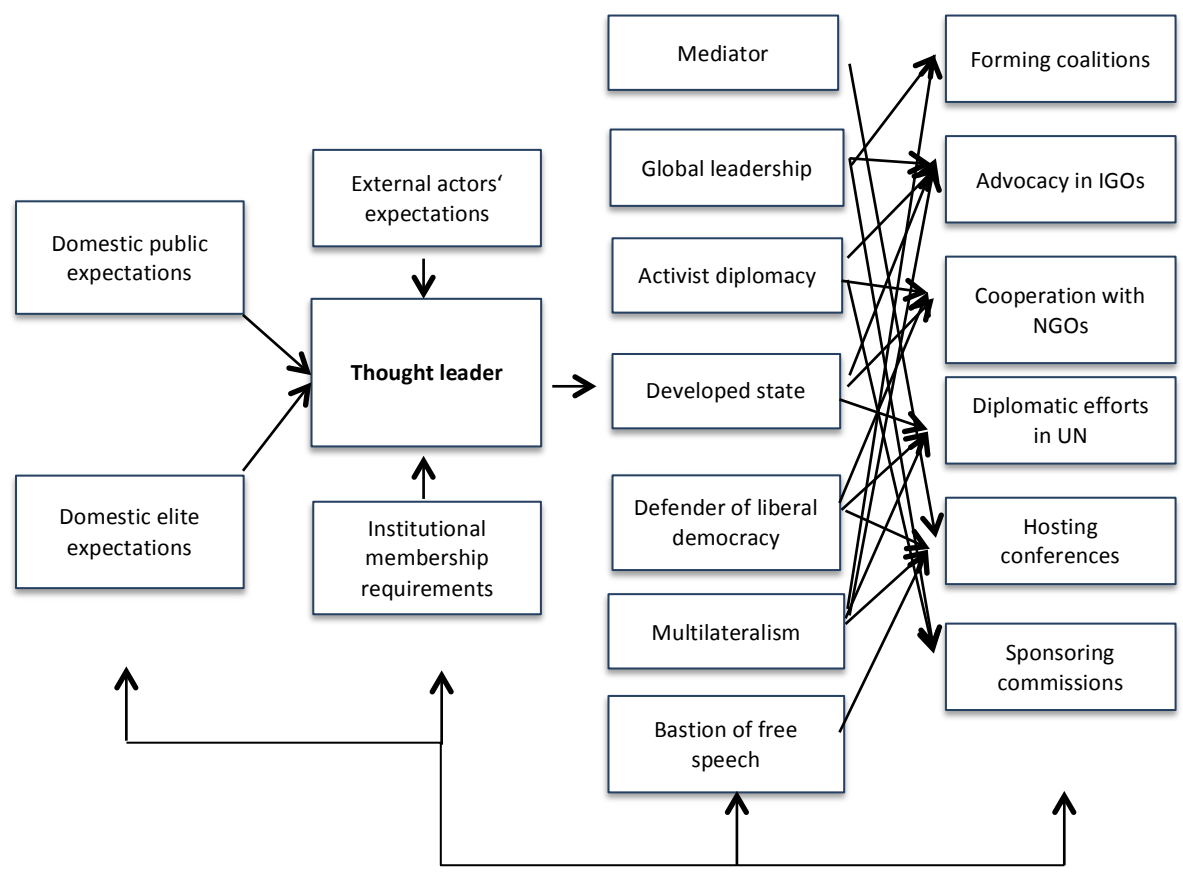

Role orientation Role conceptions

Role performance

a prominent position in global debates. In essence, they are a form of 'activist' diplomacy..$^{\circ}$ Indeed, the 2012 Foreign and Commonwealth Office (FCO) annual report states: 'Our aim is to pursue an active and activist foreign policy. ${ }^{91}$ Perhaps one of the most overt examples of this approach has been the FCO's campaign to prevent rape and sexual violence in conflict zones. William Hague launched this initiative in May 2012 with the UN High Commissioner for Refugees special envoy, Angelina Jolie, and the two travelled to the Democratic Republic of Congo in March 2013 to raise awareness of this phenomenon prior to the G8 meeting, at which Hague argued for a new international protocol to fight impunity for these crimes. ${ }^{92}$ The result was the prominent endorsement of a 'Declaration on Preventing Sexual Violence in Conflict' by G8 foreign ministers on II April 20I3. ${ }^{93}$

Such an initiative is comparatively uncontroversial, since it is unlikely to impinge on the core national interests of other states and is clearly to the advantage of weaker members of society. An activist foreign policy could become more problematic if it seemed to be promoting sectional interests over those of

90 For a discussion on the limits of an activist approach, see Robert Jackson, The global covenant (Oxford: Oxford University Press, 2000), p. I39.

9I FCO, Annual report and accounts 2011-12, p. 3.

92 FCO, 'William Hague and Angelina Jolie visit Eastern DRC', press release, 25 March 20I3, http://www. politicshome.com/uk/article/75I20/fco_william_hague_and_angelina_jolie_visit_eastern_drc.html, accessed ro April 2014 .

93 FCO, 'G8 foreign ministers' meeting statement', II April 20I3, https://www.gov.uk/government/news/ g8-foreign-ministers-meeting-statement, accessed io April 2014. 
the wider community of the UK. An NGO can argue for action over human rights violations in Syria, for example, on the basis that its purpose is to encourage global action against such crimes. The focus of its interest is on the individuals being abused. However, policy-makers have to consider the interest of their own community first. Should they risk the lives of British soldiers to intervene in a civil war? What would be the wider implications of British involvement and how might this affect the security of British citizens and British economic assets in the region? An activist foreign policy might also run the risk of losing sight of 'grand strategy' or broader interests in favour of short-term initiatives. Being a 'thought leader' is an interesting notion, but it is not clear whether such a concept is sustainable as a guiding role orientation for the state. It does not really provide much in the way of guiding principles as to what the UK should be prioritizing, and arguably underplays the potential for conflict between communitarian needs and global public goods.

\section{Opportunist-interventionist}

The role orientation of opportunist was originally intended by role theorists to describe those statespeople and governments that seek public support and acclaim in international affairs. ${ }^{94}$ For the purposes of this article, I would like to adapt the term to refer to those who seek to exploit current disruptions in the international system to advance liberal ideas about human rights, democracy and good governance, even at the expense of existing frameworks of international law. The New Labour governments of Tony Blair were exemplary in this regard.

Since 1997 the UK has enacted the role of opportunist-interventionist power extensively, engaging in military action in Iraq (twice), Kosovo, Sierra Leone and Libya. ${ }^{95}$ This role orientation is, I would argue, a radical change from previous role-taking behaviour. New Labour's foreign policy predecessors such as Douglas Hurd may have implied that intervention in Kosovo was a natural progression from lessons learned after the Bosnian war $;^{96}$ however, the case of Kosovo represented a major development in the use of military force to promote human rights, since it involved wide-scale bombing of a sovereign state and effective annexation of its territory. It is worth contrasting the I99I Gulf War, which had the limited objective of restoring the sovereignty of Kuwait following aggression by its neighbour, with the preventive war of 2003 against Iraq to eradicate a threat that had not yet materialized. The extent of public anger over the latter intervention is a strong indication that it broke with the expectations of behaviour held by the British public on how the UK should act abroad. ${ }^{97}$

94 Hermann, 'Foreign policy role orientations', pp. I38-9.

95 Intervention in Afghanistan was represented for the most part as self-defence, and so I exclude it from this category of role performance.

${ }_{96}^{6}$ Douglas Hurd, The search for peace (London: Little, Brown, I997), p. 2II; see also David M. McCourt, 'Embracing humanitarian intervention: Atlanticism and the UK interventions in Bosnia and Kosovo', British Journal of Politics and International Relations I5: 2, 20I3, pp. 246-62.

97 For examples, see Robin Cook, resignation speech, House of Commons, I7 March 2003, Hansard (Commons), vol. 40I, cols 726-727; Simon Burall, Brendan Donnelly and Stuart Weir, Not in our name: democracy and foreign policy in the UK (London: Politico's, 2006). 
Figure 7: Opportunist-interventionist role play

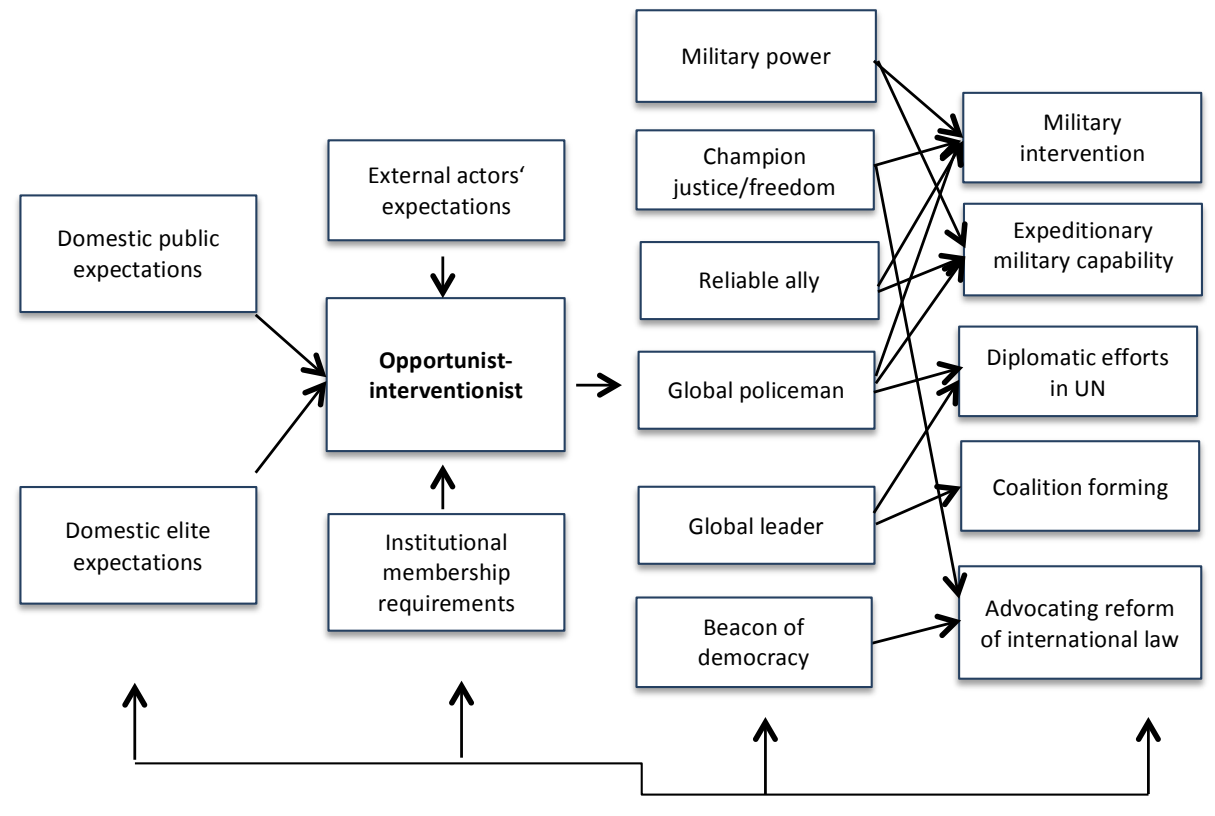

Role orientation Role conceptions Role performance

Critical scholars could argue that the UK violated the sovereignty of many states during the Cold War. ${ }^{9}$ However, what have come to be dubbed 'Blair's wars' were justified by reference to a rationale that sought explicitly to challenge prevailing ideas of sovereignty and non-intervention that were core components of the UN Charter and international law. Between 1998 and 2003, the UK arguably ceased to be a status quo power and became a revisionist one. ${ }^{99}$ Its role orientation was transformed from that of a self-declared upholder of international law to that of a state wishing to subvert existing rules to create a new order based on 'sovereignty as responsibility'. Whether this was to the benefit of the UK is contestable.

On the one hand, this role orientation did bring some measure of increased status to the UK, since it seemed to be shaping the agenda of global politics. It also reinforced the alliance with the United States. On the other hand, the opportunist-interventionist stance had a number of negative consequences. The UK was derided as the 'poodle' of the United States and arguably lost a sense of its own autonomy of action. Public support for military action wavered, and there is a sense that the British people may be tired of sacrificing money, effort and lives on crises that are remote from core British interests. In a 20Io Chatham House/ YouGov survey the public appeared to favour Britain remaining a 'great power with a large army' but one that would 'cut the overseas aid budget and use foreign

${ }^{8}$ Mark Curtis, Web of deceit (London: Random House, 2003).

99 Barry Buzan, 'China in international society', Chinese Journal of International Politics 3: I, 20Io, pp. 5-36. 
policy solely to defend Britain's national interest'. ${ }^{\text {IOo }}$ In other words, they wished to retreat from the role of an interventionist power. The sense that policy-makers were acting opportunistically rather than in measured response to external threats has also diminished trust in the intelligence services - something that could have important long-term repercussions.

Moreover, this is a role that has had a poor reception from rising powers such as China, Brazil and India. While these states may have benefited from the UK's willingness to support action in places such as Libya and Mali, they are also acutely sensitive to western powers transgressing sovereignty and seeming to reprise their past roles as imperial powers. It is arguable that Britain's role as an interventionist in Libya has allowed these states to 'free ride' on the back of western efforts to maintain regional security while benefiting from their own enactment of the roles of anti-imperialists or peaceful traders. A role orientation that comes with a high financial and reputational cost and at the same time benefits rival states would not seem advantageous to a state such as the UK which must make hard choices about how to fulfil its immediate national interests.

\section{Great Power}

The last role orientation, one that is perhaps only worth mentioning to underline how far it has faded from resonance in the UK's self-identity, ${ }^{\text {IOI }}$ is that of Great Power. Franks was accurate in his prediction that the UK would try to continue to perform this role despite the end of empire. However, it has arguably proved unsustainable in the twenty-first century. Traditional Great Power behaviour involved alliances and rivalries with other states in the pursuit of relative gains. It also implied the maintenance of a preponderance of power in key military or industrial sectors to afford a state competitive advantage in the event of war. The end of the Cold War brought an end to power blocs and made redundant European fears of major conflict. Interstate rivalry still exists, but it is for the most part economic rather than military power that counts in a world of dense multilateral institutionalization. That is not to say that such behaviour might not return. Moscow's recent interventions in Georgia and Ukraine could presage a future era of tense relations between Russia and Europe. However, the weak response of European powers to these interventions suggests they have little stomach for overt conflict. When it comes to Great Power competition in other regions, such as Asia, the population size and material resources of the rising powers are such that the UK could not compete with them even if it wished to do so.

The 20Io SDSR could be seen as a final recognition that the UK can no longer play a Great Power role. According to Anthony King, retaining the capacity to deploy a division-sized force overseas was vital to a state's continuing to belong

${ }^{\text {100 }}$ Chatham House/YouGov, British attitudes. Meanwhile, elite respondents to the survey wanted 'Britain to give up the attempt to remain a Great Power and instead to seek influence in today's world by setting a good example - with an ethical foreign policy and large overseas aid budget'.

го $A$ possible exception is Justin Morris, 'How Great is Britain? Power, responsibility and Britain's future global role', British Journal of Politics and International Relations $13: 3$, 20II, pp. 326-47. 
Figure 8: Great Power role play

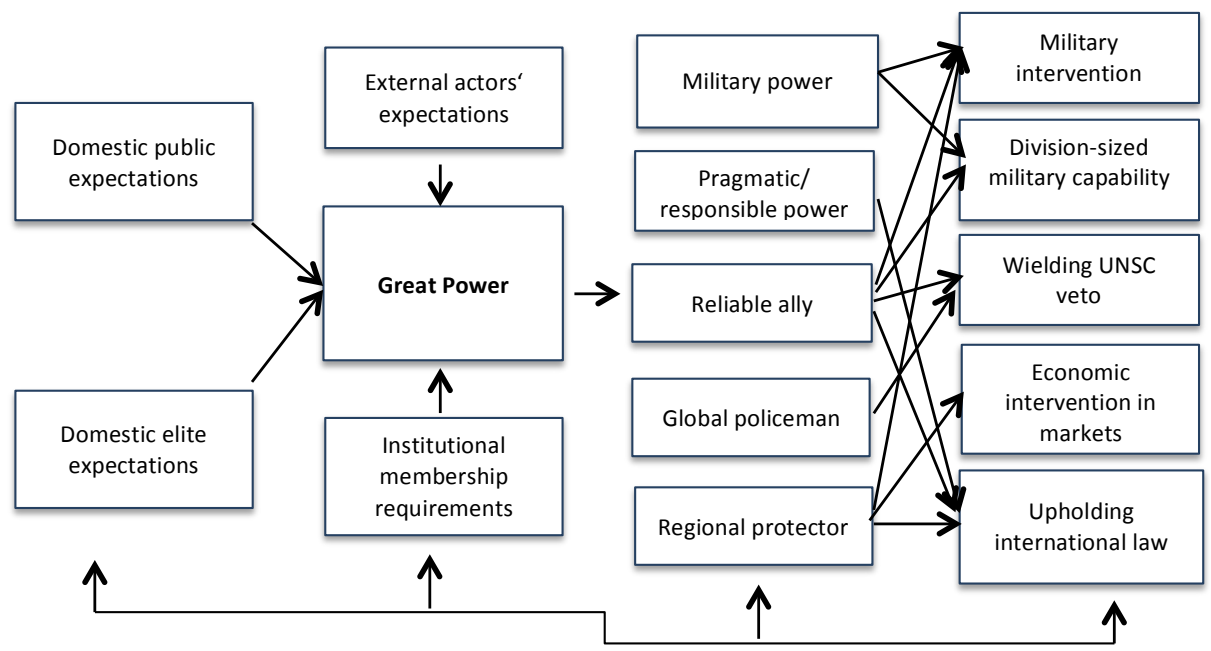

Role orientation Role conceptions

Role performance

to the 'elite club of great powers'. ${ }^{\text {IO2 }}$ The SDSR has reduced Britain's capacity to intervene abroad to that of a brigade, and as such effectively ended the UK's ability to deploy, long term, the sort of force used in the Gulf Wars in I99I and 2003. The fact that these commitments were justified as part of Britain's obligations as a major power to uphold international law indicates that this is not a role which policy-makers wish to fulfil in the future. The SDSR suggests that from now on operations will only be conducted with allies, and so force levels can be reduced without a loss of influence. However, a key part of the assessment of a Great Power is its capacity to act independently. ${ }^{\text {IO3 }}$ Even if the UK tends to act in concert with others, its contribution has historically been large and this was attributable to its desire to play the part of a 'Great Power' in world politics. Financial constraints seem to have finally compelled a retreat from this role.

\section{Conclusion}

The aim of this article has been to explore some of the options available to foreign policy-makers when it comes to the UK's role in the world. Although governments often talk about introducing a more strategic sense to policy formation, they tend to skirt round the choices entailed and fall back on outdated ideas and metaphors. Instead, I have attempted to engage in a kind of thought experiment whereby the UK is able to select for itself an overarching orientation towards the international system. Six ideal-type role orientations have been outlined, and some of the costs and benefits of choosing any one posited. Pursuing a particular

\footnotetext{
${ }^{102}$ Anthony King, 'Having brigades will never deliver the same punch as a division', Parliamentary Brief Online, no. 27 , Oct. $201 \mathrm{I}$.

${ }^{103}$ John J. Mearsheimer, The tragedy of Great Power politics (New York: Norton, 2003).
} 
role orientation could bring advantages. It might result in a stronger narrative about British identity that could galvanize public support at home for British foreign policy. ${ }^{\text {IO4 }}$ In projecting this identity abroad, the UK could link foreign policy with the domestic community in such a way as to strengthen the sense that policy goals and behaviour were in pursuit of a genuinely collective or national interest. Behaving in a consistent fashion according to a defined script also allows foreign policy-makers to shape how Britain is viewed by others and to build trust in the UK's interactions abroad. ${ }^{\text {IOS }}$ Moreover, identifying the links between identity, strategy and action gives a clearer framework for devising policies. In the process, it may be possible to deploy resources more strategically in the service of policy goals.

Of course, strategic thinking needs to continually reflect upon and challenge assumptions, responding to the test of practical experience. Policy-makers should not be distracted from immediate priorities in the dogmatic pursuit of an abstract role; rather, role theory should be seen as offering a means of interpreting current events in the light of their long-term implications. Nor should role conflict be avoided at all times if the result is that policy choice loses any flexibility, is out of touch with system changes or leaves the state open to exploitation by rivals. That said, if policy-makers are to exploit the potential benefits of strategizing and committing to roles, they may have to forgo short-term advantages that could lead to role conflict for the sake of the broader identities and interests role orientations embody.

Policy-makers might be tempted to assume that the UK can adopt all or most of these role orientations at any one time. However, this fails to take into account the way in which role conflict can hamper the success of policy efforts. One cannot be an influential (rule of law) state and at the same time seek to transgress international law in an opportunist-interventionist fashion. Attempts to be an 'honest broker' and mediator, in the thought leader mould, could be hampered if the UK was overly associated with roles underpinning the existing order, or with self-interested policy-making. Tensions over British foreign policy towards Iraq, Afghanistan and Syria arguably demonstrate the importance of strategizing Britain's role in the world in a more systematic fashion. Becoming aware of role orientations, and the role conflicts that can arise within them, provides a good starting-point.

\footnotetext{
${ }^{104}$ House of Lords Select Committee on Soft Power and the UK's Influence, Persuasion and power in the modern world, 28 Mar. 20I4, HLI50, http://www.publications.parliament.uk/pa/ld20I3I4/ldselect/ldsoft power/I5o/I5o. pdf, accessed I4 April 20I4.

Ios Christopher Hill and Sarah Beadle, The art of attraction: soft power and the UK's role in the world (London: British Academy, 20I4), p. 8; Harnisch, 'Conceptualizing in the minefield', p. 54.
} 